\title{
Histoarchitecture and Histochemical Studies on the Lacrimal Gland of Pig (Sus scrofa)
}

\author{
Parveen Kumar Gahlot*, Amandeep Singh and Tej Parkash \\ Department of Veterinary Anatomy, College of Veterinary Sciences, Lala Lajpat Rai University of Veterinary and Animal \\ Sciences, Hisar, Haryana, INDIA \\ "Corresponding author: PK Gahlot; E-mail: drparveen@hotmail.com
}

Received: 03 Dec., 2019 Revised: 27 Jan., $2020 \quad$ Accepted: 31 Jan., 2020

\begin{abstract}
The fresh tissues were collected from five pigs of either sex and processed for histomorphological studies. The gland was located on dorso-lateral aspect of the eye in the orbital cavity. The gland was multilobar tubulo-acinar with predominance of acini. It was covered by a thick connective tissue capsule and connective tissue septa, which penetrate into the glandular parenchyma and divided the gland into lobes and lobules. The acini were of mixed type but predominantly sero-mucous in nature. The secretory units were followed by a duct system. The excretory duct system was made up of intercalated, intralobular, interlobular and large excretory ducts. The strong presence of glycogen in the acini was demonstrated with the help PAS (McManus') stain. The ducts showed very weak reaction for the presence of glycogen but goblet cells in the stratified ducts showed strong positive reaction for PAS. The acini showed strong reaction for acidic mucosubstances with PAS-AB. The goblet cells in the stratified ducts also showed strong positive activity towards the PAS-AB. The intense activity towards the Alcian blue showed presence of sialomucins and hyaluronic acids in glandular parenchyma of the lacrimal gland.
\end{abstract}

Keywords: Histology, Histochemistry, Lacrimal gland, Pig

The Lacrimal glands are very important glands for maintaining corneal health. The tear is having proteins and electrolytes in its secretion which is important for optics and general health of cornea and it also helps in providing protection to the eye from pathogen (Hirayama et al., 2013; Pinard et al., 2003). Proteins in the tear plays an important role in protecting the ocular surface from the pathogens, maintaining the integrity and stability of the tear and modulating the ocular wound healing process (Zhou et al., 2007). Dry eye syndrome (DES), also known as keratoconjunctivitis sicca, is a common affection in porcine and human with symptoms like irritability, visual impairment, and tears film damage which leads to potential damage to the eye. The lacrimal glands of human beings, dogs, cats, horses, pigs, rabbits, sheep and goats have been described in the literature (Prince et al., 1960; Sinha and Calhoun, 1966; Allen et al., 1972; Krochmalska, 1976; Gillette et al., 1980; Martin et al., 1988; Singh et al., 2018). But there is paucity of literature regarding the histological and histochemical study of lacrimal gland in pigs. The present study was taken up to describe the histological and histochemical aspects of the lacrimal gland in pigs.

\section{MATERIALS AND METHODS}

\section{Collection, fixation, processing and staining of tissues}

The lacrimal glands were collected from five apparently healthy young pigs of local mixed breed of either sex. The pig eyes were collected from local slaughter house immediately after decapitation and the tissues were fixed in a $10 \%$ neutral buffered formalin solution for $48-72$

How to cite this article: Gahlot, P.K., Singh, A. and Parkash, T. (2020) Histoarchitecture and histochemical studies on the lacrimal gland of pig (Sus scrofa). J. Anim. Res., 10(1): 117-121. 
hrs. The tissues were processed for light microscopic examination and embedded in paraffin blocks. The paraffin sections $(5-6 \mu)$ were made through the entire gland and stained with routine Harris' hematoxylin and eosin stain for general histomorphological examination, Gomori's stain for reticular fibres, Weigert's method for elastic fibres (Luna, 1968) and Crossman's trichrome stain for collagen fibres (Crossman, 1937). In addition, selected sections were processed for histochemical demonstration of mucopolysaccharides using PAS-Alcian blue, Alcian blue, PAS (|McManus') method, colloidal iron method and Mayer's mucicarmine method (Luna, 1968).

\section{RESULTS AND DISCUSSION}

The gland was located on dorso-lateral aspect of the eye in the orbital cavity as reported in pigs (KleckowskaNawrot and Dziegiel, 2008; Henker et al., 2013). Similar observations were reported in other animals like sheep (Singh et al., 2018), Iranian river buffalo (Abbasi et al., 2014) and dogs (Shaker et al., 2016). The gland was a multilobar tubuloacinar gland with predominance of acini over tubules (Fig. 1a).

It was covered by a thick connective tissue capsule, consisting of collagen and elastic fibers. The capsular connective tissue penetrated into the glandular parenchyma forming the septa, which divided the gland into lobes and lobules. These lobules were represented by the secretory end pieces and duct system. The glandular tissue was consisted of serous acini and mucous acini

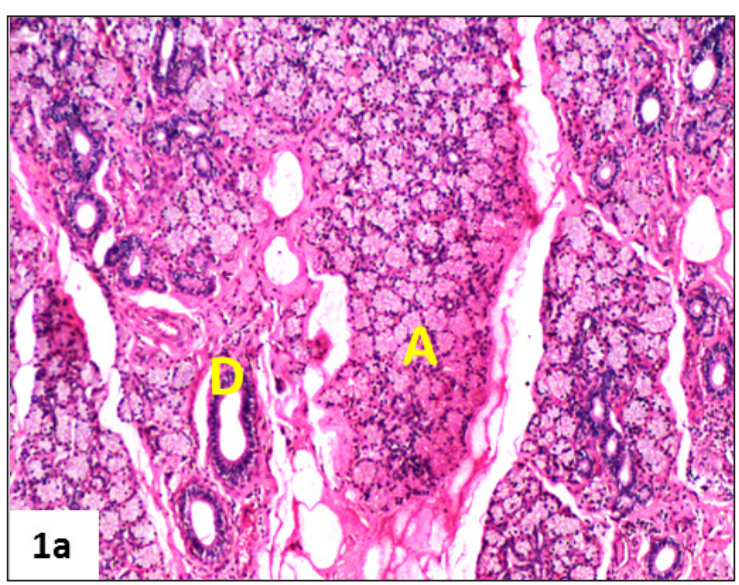

and sero-mucous (mixed) secretory units (Fig. 1a and 1b) which were in agreement with the findings in pigs (Kuhnel and Scheele, 1979; Gargiulo, et al., 1999), sheep (Singh et al., 2018) and buffaloes (Girgiri and Kumar, 2018). In contrast, canine lacrimal glands were reported as being purely mucus-secreting glands (Martin et al., 1988) and goat as serous (Alsafy, 2010). The lacrimal gland in camel was consisted of serous and mucous acini (Ibrahim and Abdalla, 2015). The acini of irregular lumen were composed of conical to pyramidal cells surrounded by basal myoepithelial cells. The big and round secretory cell nuclei were located in their basal part. These cells showed weakly eosinophilic and granular cytoplasm.

The plasma cells with a characteristic basophilic nucleus and eosinophilic cytoplasm and sparse amount of lymphocytes were observed in the glandular interstitial tissue (Fig. 1b). The secretory units were followed by a duct system. The excretory duct system was made up of intercalated, intralobular, interlobular and large excretory ducts (Fig 1a, 1b. ) as revealed in pigs (Kuhnel and Scheele, 1979) and other species like sheep (Singh et al., 2018) and buffaloes (Girgiri and Kumar, 2018). In contrast, the duct system of lacrimal gland of dog was started with intralobular (Shaker and AL-Obeady, 2016). The intercalated tubules with large lumen were composed of single layer of cuboidal cells with round nuclei, located in the basal area of the cells which were in agreement with the findings in pig

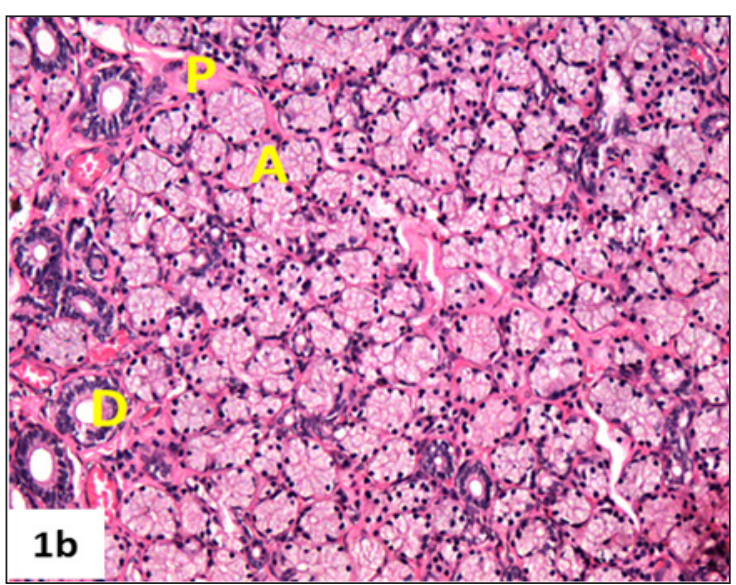

Fig. 1a. Photomicrograph of lacrimal gland of pig showing acinar cells (A) and interlobular ducts (D) (H \&E x100). (1b) Photomicrograph showing the interstitial tissue present between adjacent secretory units (A) contains numerous small blood vessels and nerves, interlobular ducts (D) and scattered plasma cells (P) in the lacrimal gland of pig (H \&E x200) 
(Kuhnel and Scheele, 1979). The intralobar ducts were varied from bistratified cuboidal to simple columnar type. The interlobar ducts showed irregular lumen and lined with stratified columnar epithelium with large goblet cells. The blood vessels and nerve bundles were observed in between inter lobular spaces.

Histochemical studies indicated the strong presence of neutral mucopolysaccharides in the acini, which was demonstrated with the help of PAS method (Fig. 2a). These observations were in agreement with the
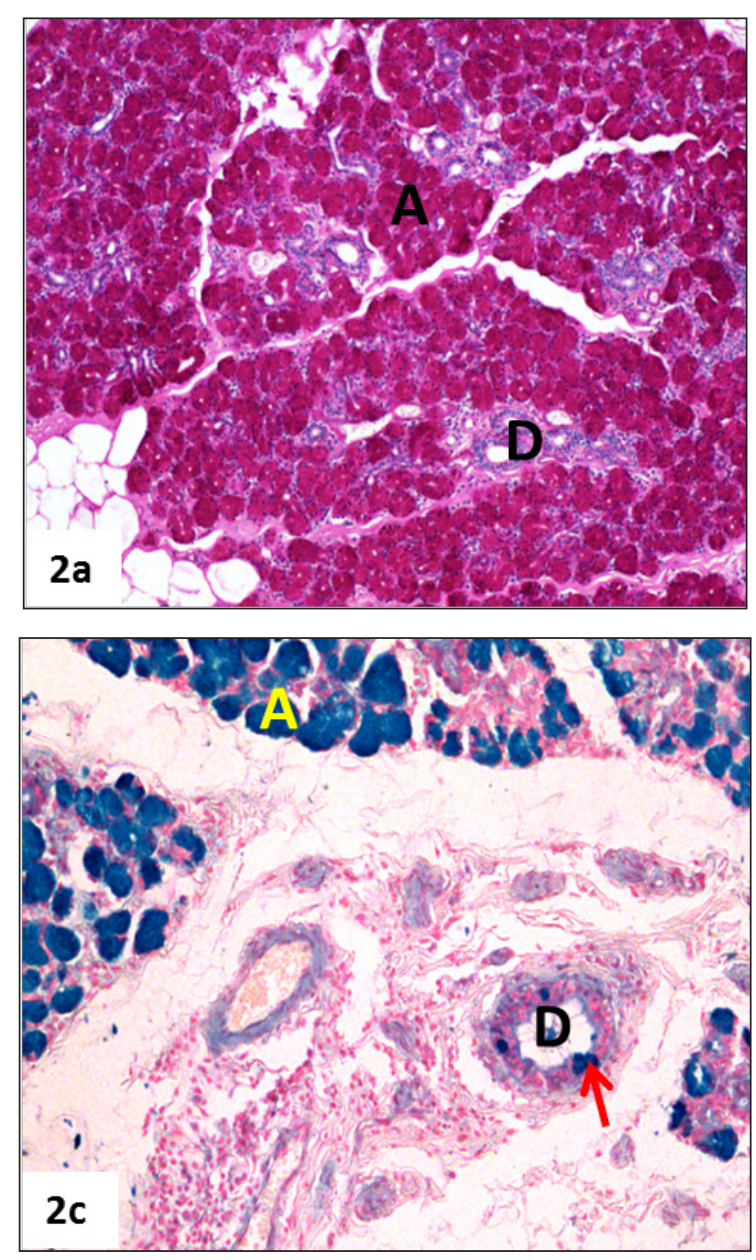

earlier findings in sheep (Singh, et al., 2018), camel (Mohammadpour, 2011), however a strong PAS positive reaction was observed in mucous cells and a weak PAS positive reaction in seromucous cells of small ruminants Gargiulo et al. (1999). The acini showed strong presence of acidic and neutral mucopolysaccharides with PAS-AB stain (Fig. 2b) as reported in buffalo (Girgiri and Kumar, 2018), whereas in sheep (Singh et al., 2018) showed presence of both acidic and neutral mucopolysaccharides with predominanace of neutral
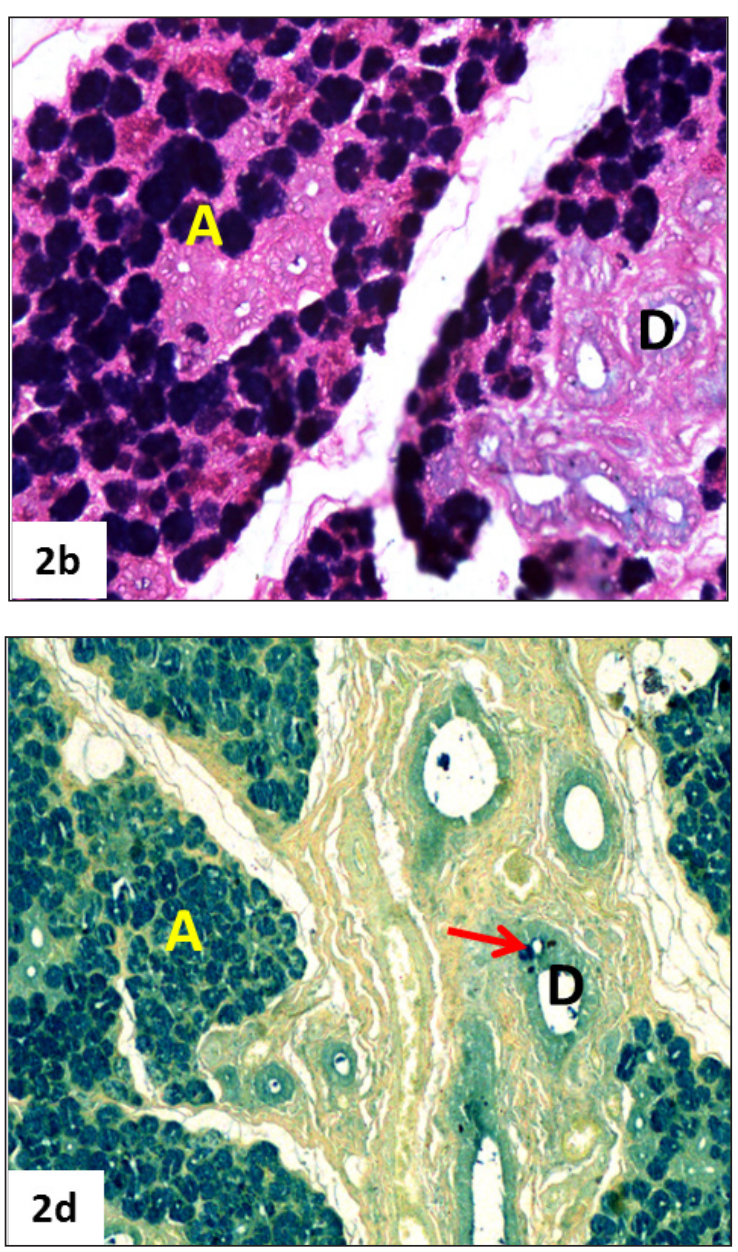

Fig. 2a. Photomicrograph showing a strong periodic acid-Schiff (PAS) positive reaction in the secretory units (A) of the lacrimal gland of pig indicating the presence of high amount of neutral mucopolysaccharides however, the epithelium of all the ducts (D) showed negative reaction (PAS x100). (2b) Photomicrograph of lacrimal gland of pig showing strong positive reaction for both neutral as well as acid mucopolysaccharides in the secretory units (A), however ducts (D) showed negative reaction (PAS-AB x100). (2c) Photomicrograph of lacrimal gland of pig showing a moderate acidic sulfated mucosubstances, sialomucins and hyaluronic acid in the secretory units (A) and goblet cells (arrow) whereas interlobular ducts (D) revealed negative reaction (Alcian blue x100). (2d) Photomicrograph of lacrimal gland of pig showing strong positive reaction for acid mucopolysaccharides in the secretory units (A) and goblet cells (arrow), however ducts (D) showed negative reaction (Colloidal Iron x100) 
one. The strong alcianophilic activity was observed towards the Alcian blue (pH 2.5) showing presence of weakly acidic sulfated mucosubstances, sialomucins and hyaluronic acids in glandular parenchyma of the gland (Fig. 2c) as reported in buffalo (Girgiri and Kumar, 2018), whereas sheep (Singh et al., 2018) and small ruminants (Triveni et al., 2017) alcianophilic activity was moderately positive. The reaction towards Colloidal iron (Fig. 2d) and Meyer's mucicarmine was observed positive in acini as reported in sheep (Singh et al., 2018). The goblet cells in the stratified ducts also showed strong positive activity towards the same. The epithelium of all ducts showed negative reaction for PAS, PAS-AB and $\mathrm{AB}$ methods. However, the goblet cells in the interlobular ducts of small ruminants showed strong positive activity towards PAS, PAS$\mathrm{AB}$, Alcian blue and colloidal iron (Figs. 2c and 2d) as reported in sheep (Singh et al., 2018) and small ruminants (Triveni et al., 2017).

\section{CONCLUSION}

It may be concluded that the lacrimal gland was a capsulated multilobular tubulo-acinar in nature. The lobes consisted of acini, which were of mixed in nature but predominantly sero-mucous in nature. The excretory duct system was made up of intercalated, intralobular, interlobular and large excretory ducts. The acini showed strong presence of glycogen, mixed mucosubstances, sialomucins and hyaluronic acids in the acini. The ducts showed very weak reaction for presence of glycogen and mucosubstances.

\section{Acknowledgements}

We are thankful to Lala Lajpat Rai University of Veterinary and Animal Sciences (LUVAS), Hisar for providing all type of facilities to carry out the study.

\section{REFERENCES}

Abbasi, M., Karimi, H. and Gharzi, A. 2014. Preliminary anatomical and histological study of lacrimal gland in Lori sheep. J. Vet. Sci. Technol., 5: 154.

Allen, M., Wright, P. and Reid, L. 1972. The human lacrimal gland. A histochemical and organ culture study of the secretory cells. Arch. Ophthal., 88: 493-497.
Crossman, G.A. 1937. A modification of Mallory's connective tissue stain with a discussion of principles involved. Anat. Rec., 69: 33-38.

Gargiulo, A.M., Coliolo, P., Ceccarelli, P. and Pedini, V. 1999. Ultrastructural study of sheep lacrimal glands. Vet. Res., 30: 345-351.

Gillette, T.E., Allansmith, M.R., Greiner, J.V. and Janusz M. 1980 Histologic and immunohistologic comparison of main and accessory lacrimal tissue. Am. J. Ophthalmol., 89: 724 730 .

Girgiri, I.A. and Kumar, P. 2018. Histological and histochemical studies on the lacrimal gland of buffaloes (Bubalus bubalis). Sch. J. Agric. Vet. Sci., 5: 283-289

Henker, R., Scholz, M., Gaffling, S., Asano, N., Hampel, U., Garreis, F., Hornegger, J. and Paulsen, F. 2013. Morphological Features of the Porcine Lacrimal Glandand Its Compatibility for Human Lacrimal Gland Xenografting. Plos One, 8(9): e74046

Hirayama, M., Ogawa, M., Oshima, M., Sekine, Y., Ishida, K., Yamashita, K., Ikeda, K., Shimmura, S., Kawakita, T., Tsubota, K. and Tsuji, T. 2013. Functional lacrimal gland regeneration by transplantation of a bioengineered organ germ. Nat. Commun., 4: 2497.

Ibrahim, Z.H.M.A. and Abdalla, A.B. 2007. A morphometric study of the lacrimal gland of the camel (Camelus dromedarius). Sudan J. Sci. Technol., 8: 40-45.

Kleckowska-Nawrot, J. and Dziegiel, P. 2008. Morphology of lacrimal gland in pig fetuses. Anat. Histol. Embryol., 37: 74-77.

Krochmalska, L. 1976. Histological and histochemical picture of the lacrimal gland in guinea pig. Acta Theriogenol., 21: 31-36.

Kühnel, W., Scheele, G. 1979. On the ultrastructure of the lacrimal gland in pigs. Anat. Anz., 145: 87-106.

Luna, L.G. 1968. Manual of Histologic Staining methods of Armed Forces Institute of Pathology. $3^{\text {rd }}$ edn., McGraw Hill Book Co., New York.

Martin, C.L.J., Munnel, J.F. and Kaswan, R. 1988. Normal ultrastructure and histochemical characteristics of canine lacrimal glands. Am. J. Vet. Res., 49: 1566-1572.

Mohammadpour, A.A. 2011. Histochemistry of dorsal lacrimal gland in camel (Camelus dromedarius). J. Camel Pract. Res., 18: $131-133$.

Pinard, C.L., Weiss, M.L., Brightman, A.H., Fenwick, B.W. and Davidson, H.J. 2003. Normal anatomical and histochemical characteristics of the lacrimal glands in the American bison and cattle. Anat. Histol. Embryol., 32: 257-262. 
Prince, J.H., Diesen, C.D., Eglitis, I. and Ruskell, G.L. 1960. Anatomy and histology of the eye and orbit in domestic animals. CC Thomas publisher, Illinois U.S.A. pp. 44-58.

Shaker, M.M. and Walaa, F.O.AL-Obeady. 2016. Anatomical and histological study of the lacrimal gland of the adult male dog (Canis familaris). G.J. Bio. Sci. Biotec., 5(4): 520-524.

Singh, A., Kumar, P., Gahlot, P.K. and Parkash, T. 2018. Histomorphochemical characterization of the lacrimal gland of sheep (Ovis aries). Indian J. Vet. Anat., 30: 131-133.

Sinha, R. and Calhoun 1966. A gross, histologic and histochmeical study of the lacrimal aparatus of sheep and goat. Am. J. of Res., 27: 1633-1640.
Triveni, T., Pawar, A., Girish, M.H. and Kumar, D. 2018. Comparative histochemical studies of lacrimal gland in ruminants. Indian J. Anim. Res., 55: 1667-69.

Zhou, L., Beuerman, R.W., Huang, L., Barathi, A., Foo, Y.H., Li, S.F.Y., Chew, F.T. and Tan, D. 2007. Proteomic analysis of rabbit tear fluid: Defending levels after an experimental corneal wound are correlated to wound closure. Proteomics. 7: 3194-3206. 
